\title{
1. A question of primacy? Japan, Australia and the future of the United States in Asia
}

Michael Heazle and Andrew O'Neil

Since 1945 the American strategic presence in Asia has been central to the region's geopolitical evolution. For most of the post-war period, this has been based on military pre-eminence and unrivalled economic influence through major trade and investment ties with individual countries in Asia. The US strategic presence has been generally regarded as a stabilizing influence on the region's geopolitics, and America's role in reassuring allies and deterring adversaries has provided a critical degree of certainty in Asia. All of this has been underpinned by the historically unprecedented material power advantages enjoyed by the US over all other states. As one account has noted, 'the depth, scale and projected longevity of the US lead in each critical dimension of power are noteworthy. But what truly distinguishes the current distribution of capabilities is American dominance in all of them simultaneously'. ${ }^{1}$

The pre-eminence of the US in material power terms is key in explaining the long and enduring shadow of America's post-war strategic presence in Asia, but it is Washington's willingness to exercise leadership that has provided the critical agency for its strategic presence. The purpose of this book is to help develop a better understanding of the role of US leadership, and the liberal order it underpins in Asia, as a driver of Australia-Japan security relations. Explaining the linkage between how Australia and Japan perceive their respective relationships with the US, we argue, will reveal important insights into both the prospects for and extent of further security cooperation between these two key US allies,

1 Stephen G. Brooks and William C. Wohlforth, World Out of Balance: International Relations and the Challenge of American Primacy (Princeton: Princeton University Press, 2008), pp. 34-5. 
the nature of US leadership in the Asia-Pacific and its prospects, and thus how the existing regional order is likely to evolve in the current strategic climate.

Indeed, US leadership is pivotal to continuing tensions in East and South-East Asia. China is challenging it, some in ASEAN are ambivalent about it, but Australia and Japan clearly want US leadership to remain. Despite the change in presidential administration in Washington, and persistent doubts about President Trump's commitment to allies, senior US officials have been quick to reaffirm a willingness to use military force to defend the territorial interests of allies in Asia. But what does it mean to speak of US leadership in this context? Japanese and Australian governments continue to highlight what they regard as the link between ongoing US military, economic and political engagement and the region's stability and prosperity. Focusing on Australian and Japanese perceptions of America's leadership role, as distinct from their different perceptions of China per se, is important for two reasons.

First, as two of the region's most militarily capable and diplomatically proactive US allies, Australia and Japan's perceptions of American leadership and its future trajectory are critical indicators of the prospects for change in the regional order. And while a discernible drift away from the current US-led order towards China on the part of ASEAN as a group would certainly indicate the inevitability of change, this is not likely for the foreseeable future, given the diverse interests within ASEAN and the strong divisions over China among ASEAN member states. ${ }^{2}$

Second, the very different balance of threat perceptions of China held by Australia and Japan has not impeded accelerated security cooperation between Canberra and Tokyo since the conclusion of the landmark Joint Declaration on Security Cooperation in 2007. Both sides have worked hard to build more intimate strategic ties in the domain of intelligence

2 ASEAN's divisions over China stem from the many differences in economic development, interests, geographical location, and political systems within ASEAN. In addition to preventing any meaningful statement on China's pursuit of its territorial claims in the South China Sea under the grouping's consensus requirement, these divisions are also dividing the ASEAN grouping in strategic terms as pressure builds to either 'bandwagon' with China, or balance against it. Some states, like Cambodia, Laos, Thailand and increasingly the Philippines under Duterte appear to be bandwagoning with China, while others, such as Vietnam, so far have chosen to balance against it by looking to the US, and Japan, for support. Malaysia and Indonesia are best described as buckpassing, with Singapore attempting to hedge between the US and China. 
sharing and military cooperation, as well as increasingly regular interaction between senior national security officials. This suggests that threat perceptions of China are not the major driver of this sustained security engagement, or perhaps even a necessary condition for this cooperation to occur.

This is supported further by the fact that Australia and Japan's efforts to keep the US engaged in the Asia-Pacific began in the early 1990s and culminated in the first meeting of the US, Australia, Japan Trilateral Security Dialogue in 2006. Significantly, enhanced Australia-Japanese security cooperation was first mooted at a time when China's rise still was widely believed to be benign and status quo orientated. ${ }^{3}$ Australia's lower threat perception of China relative to that of Japan suggests that Australia's strategic thinking is influenced more by US engagement and its linkage with both ANZUS and the regional order more broadly. To quote Glosserman, this potentially makes Australia 'the canary in the regional security coal mine'. ${ }^{4}$

The strong Australian and Japanese commitment to keeping the US engaged and the current order in place has made responding to China's rise in a way that threatens neither regional stability nor economic relationships with Beijing a prominent policy challenge for Canberra and Tokyo. Much of the analysis and commentary so far on the efficacy of greater Australian and Japanese security engagement as a means to this end has focused on their respective threat perceptions of China to explain not only their shared strategic interests, but also the limits to bilateral security cooperation between them (for instance, the so-called China Gap). But rather than focus primarily on the differences in the perceptions of threat in relation to China, the prospects for deeper AustraliaJapan security cooperation can also be appreciated by examining what is common to both countries in terms of their perceptions of their evolving parallel alliances with the US and the need for further cross-bracing; the depth of their shared commitment to the US-led regional order; and the degree to which Australia and Japan will share overlapping interests in their strategic outlooks in coming years.

The major goals of this book are to examine how Australia and Japan regard US leadership in the region through the lens of their respective alliance relationships; how their perceptions of the US and the associated

3 See Michael Heazle and Yuki Tatsumi, 'Explaining Australia-Japan Security Cooperation and its Prospects: "The Interests that Bind?"' The Pacific Review (2017). Available at: http://dx.doi.org/10.1080/09512748.2017.1310750.

4 Brad Glosserman, 'The Australian Canary'. The Diplomat (23 November 2011). Available at: http://thediplomat.com/2011/11/the-australian-canary/. 
importance they place on the current order shape the bilateral relationship between Canberra and Tokyo; and finally to provide guidance on the options for promoting regional stability and continued US engagement. The three central questions that thread through the analysis of contributors are:

1. How far are Japanese and Australian policy makers likely to go in keeping the US committed to strategic engagement in the AsiaPacific?

2. What does maintaining a commitment to US leadership mean in terms of bilateral security cooperation between Australia and Japan?

3. How can Australia and Japan most effectively manage the risk of either a declining US commitment, or a US-China military confrontation?

\section{PRIMACY OR HEGEMONY? THE SOURCES AND NATURE OF US LEADERSHIP}

To understand more fully the depth of Australia and Japan's commitment to US leadership and engagement in the region, and by association the prospects for continuing bilateral and trilateral security cooperation, we first need to consider what kind of leadership the US provides in Asia. The character, perceptions and expectations of US leadership within a 'liberal' regional order thus are all integral to the book's focus on explaining the importance and influence of continuing US leadership and engagement on policy thinking in Australia and Japan. The strong desire among states more broadly for ongoing US engagement is evidenced by the growing consternation in Asia and Europe over the prospect of the Trump administration decreasing the US commitment to its allies and partners. These concerns are exacerbated by the perceived scope for the US-led order in Asia to be supplanted by a China-led order based on interests and priorities determined by Beijing. A widely held perception exists in the region that the existing order under US patronage is preferable to one led by China. Some states are open about this, while others are content to lobby the United States behind the scenes to maintain its strategic commitments in Asia.

The qualitative difference between a US-led or Chinese-led order, and the sources of authority they depend on, is often lost in discussion and debate over the status and future of America's role due to lack of clarity and consistency in the terms used to describe it. Dominance, hegemony 
and primacy are the most common terms used in the literature to describe the US role and status despite the various, and at times contradictory, meanings attributed to these terms by scholars and commentators. How, then, can we achieve greater conceptual clarity and a better understanding of the character of US leadership and why so many states remain committed to it? Helping resolve this ambiguity over the character of US leadership is important if we are to move beyond the many existing arguments about what a relative decline in US material power means for the regional order. Doing so may also be helpful in ensuring that disagreements over the nature of US leadership and its prospects are in fact focused on commonly understood terms.

The material dimensions of US power are routinely cited when invoking US primacy or hegemony, but they are also regularly mixed and interchanged with other equally important sources of US power, such as influence, consent and legitimacy. As a consequence, the specific nature of US power, the order it supports, and why it may be preferable to the alternatives (for example, a more hierarchical, less consensual order led by China) is at times unclear in the various debates over how US allies and others should respond to the region's increasingly fluid security environment. Should formal allies like Australia, Japan, South Korea and the Philippines continue to commit to the current US-led order? If so, at what price? Should they be open to operating in a different kind of order, either with Beijing as the dominant power or some type of US-China G2 arrangement? Alternatively, should they be moving towards a more independent approach, seeking to either balance internally - including in one or two cases through an independent nuclear capability - or externally, through alliances and/or multilateral security networks with like-minded states?

Discussing US leadership of the Asia-Pacific and its significance using language that describes, or is commonly accepted as describing, little more than its superior military and economic capabilities ignores the more complex political context in which US power is applied and the ends to which it is applied; this makes it difficult to articulate clear cases for or against the above policy choices. If, for example, the US leads primarily because it is militarily and economically dominant in material terms, why should states in the region be concerned by China's rise and its potential to become the new regional hegemon? Why not simply swap sides and leaders, or at least grant China a power-sharing role, which some argue is far preferable to the prospect of war? However, the prospect of a US withdrawal or declining commitment over time to the region is clearly not in everyone's interests. As the public statements and behaviour of several US allies and regional security partners indicate, 
there is much more than just material power behind the authority US leadership carries and the sources of legitimacy it relies on to exercise leadership.

Concern over the possible decline of US power and especially its commitment to underwriting security in Asia, moreover, is not new. In the post-1945 period, doubts have persisted over Washington's willingness and capacity to sustain a leadership role in the region. These doubts were especially salient following President Nixon's promulgation of the Guam doctrine in 1969, the end of the Cold War in the early 1990s, and the Bush administration's post-9/11 preoccupation with the Middle East. With China's growing military and economic capability, and its apparent goal of challenging US pre-eminence in Asia, these doubts have once more been raised, and are now a salient feature of government and academic debates in the US and throughout the region.

These debates have revealed two interlinked, but nevertheless distinct, sets of issues. The first set deals with questions surrounding China's intentions, motivations and capabilities, culminating in the long-running debate over whether China is a revisionist or status quo power. The second set of issues relates to the strategic implications of China's rise and Beijing's apparent intention to challenge the US-led liberal order. The first debate, we contend, has largely been resolved. Given China's actions in the South and East China Seas, it is now difficult to argue the status quo case for China. This edited volume therefore turns instead to the second debate by focusing on Australian and Japanese perceptions of what China's rise means for the current order and the significance of continuing US leadership.

This more foundational debate over the costs and benefits of maintaining the region's US guaranteed 'rules-based' order in the face of challenges by China, or another more radically revisionist state like North Korea, however, has suffered from lack of clarity on the nature of the US role in preserving the existing order. This includes the means by which the US is believed to do so. The conceptual ambiguity surrounding the character of US leadership and engagement and what it means for others in the region is most clearly illustrated by the often bewildering array of terms used to describe the US role and its sources of influence and power. $^{5}$

Some experts treat primacy, hegemony and dominance as labels describing a strategic goal, some to describe a strategy, others for

5 Ian Clark, 'Bringing Hegemony Back In: The United States and International Order'. International Affairs, Vol. 85, No. 1 (2009), pp. 23-36. 
describing both, and still others as little more than a structurally determined condition of international politics. Many randomly substitute one for the other in making arguments about US intent and purpose, attributing no difference in meaning. Some distinguish between them by tying US primacy exclusively to unipolarity as Posen and others ${ }^{6}$ have done, arguing it has only existed since the end of the Cold War, or alternatively by using it only to explain 'hawkish and hard line' behaviour such as the unilateralist policies of the George W. Bush administration. ${ }^{7}$ Layne, in contrast, equates unipolarity ${ }^{8}$ with hegemony in one instance, and in another qualifies 'good' hegemony as practicing multilateral engagement. Primacy is both 'the most important factor in maintaining global and regional stability' but also presented by Layne as the flip side of good hegemony, that is, US power exercised unilaterally. ${ }^{9}$ Others, such as Walt ${ }^{10}$ and Ikenberry, ${ }^{11}$ instead argue that US primacy and/or hegemony have all been in place since 1945 .

Yet Mearsheimer and Walt, when writing on offshore balancing, limit US hegemonic influence geographically. Offshore balancing, in their view, discounts any global form of hegemony since it means distinguishing between the need to protect US hegemony (dominance) in the Western hemisphere while maintaining only primacy, rather than dominance, elsewhere by helping allies to balance against the rise of any regional hegemons in key theatres such as East Asia, Europe or the Middle East. Under offshore balancing, according to Mearsheimer and Walt, not only is the US not a hegemon outside of its own region, but it

6 Barry R. Posen, Restraint: A New Foundation for US Grand Strategy (Ithaca: Cornell University Press, 2014); Stephen G. Brooks and William C. Wohlforth, 'American Primacy in Perspective'. Foreign Affairs, Vol. 81, No. 4 (2002), pp. 20-33; Eric Edelman, Understanding America's Contested Primacy. Center for Strategic and Budgetary Assessments (21 October 2010). Available at: http://csbaonline.org/research/publications/understanding-americas-contestedprimacy.

7 David McDonough, 'Beyond Primacy: Hegemony and "Security Addiction” in US Grand Strategy'. Orbis, (Winter 2009), pp. 6-22. See also Posen, Restraint, pp. 8-10.

8 Christopher Layne, 'The Waning of US Hegemony - Myth or Reality? A Review Essay'. International Security, Vol. 34, No. 1 (2009), pp. 147-72.

9 Christopher Layne, 'Offshore Balancing Revisited'. The Washington Quarterly, Vol. 25, No. 2 (2002), p. 234.

10 Stephen M. Walt, 'American Primacy: Its Prospects and Pitfalls'. Naval War College Review, Vol. 55, No. 2 (2002), pp. 9-28.

11 G. John Ikenberry, 'The Future of the Liberal World Order'. Foreign Affairs, Vol. 90, No. 3 (2011), pp. 56-62. 
does not (and should not) harbour hegemonic ambition beyond its own part of the world. ${ }^{12}$

Some instead seek to describe hegemony in terms of its configuration rather than in sphere of influence terms. According to Clark, hegemons can be collective, singular or, in the case of the US, 'coalitional'. Like Reus-Smit, ${ }^{13}$ Clark takes a Gramscian position on hegemony, ${ }^{14}$ insisting a truly hegemonic order or leadership must be legitimate, an institution made legitimate by the consent of other states. ${ }^{15}$ Under this criterion, it is hard to argue the existence of any form of international hegemony, either now or in the past, which is what Clark believes to be the case. Ikenberry too seems to see the US more in Gramscian terms, describing it as a benign hegemon and inferring consent, while referring to international life under US leadership and the liberal order it supports (specifically in East Asia) ${ }^{16}$ as 'liberal' hegemony. However, Ikenberry, Clark and Reus-Smit's institutional depictions of liberal hegemony raise the question of whether the dominance and hierarchy normally associated with hegemonic power and influence - consent-based, unipolar or otherwise is compatible with the core liberal notions of equality and independence among states that a 'liberal' international order necessarily rests on. Jervis, for example, raises this problem in his discussion of unipolarity, noting that: 'These [liberal] values ... may not be fully compatible with unipolarity. International liberalism implies juridical equality among states'. ${ }^{17}$

And even in Gramscian-type presentations of hegemony emphasizing legitimacy and consent, there remains the question of how an international and anarchical system of diverse states could consent to the

12 John J. Mearsheimer and Stephen M. Walt, 'The Case for Offshore Balancing: A Superior US Grand Strategy'. Foreign Affairs, Vol. 95 (July/August 2016), pp. 70-83.

13 Christian Reus-Smit, American Power and World Order (Cambridge: Polity Press, 2004), pp. 44-5.

14 Robert W. Cox, 'Gramsci, Hegemony and International Relations: An Essay in Method'. Millennium: Journal of International Studies, Vol. 12, No. 2 (1983), pp. 162-75; Thomas Bates, 'Gramsci and the Theory of Hegemony'. Journal of the History of Ideas, Vol. 36, No. 2 (1975), pp. 351-66.

15 Clark argues that US hegemony has not existed; only periods of primacy. Ian Clark, Hegemony in International Society (Oxford: Oxford University Press, 2011).

16 G. John Ikenberry, 'American Hegemony and East Asian Order'. Australian Journal of International Affairs, Vol. 58, No. 3 (2004), pp. 353-67.

17 Robert Jervis, 'Unipolarity: A Structural Perspective'. World Politics, Vol. 61, No. 1 (2009), pp. 188-213, at 202. 
dominance of one, or several, states. It may, in some sense at least, be more liberal even if dominance with consent between states were possible, but it would certainly no longer be anarchical. We would instead have some form of international 'benevolent dictatorship' in which the idea of independent states (or potentially even 'international relations') would be no longer relevant. T.V. Paul also implies that hegemony need not require dominance, describing the US as a "constrained' hegemon. But he offers little explanation, beyond 'a multitude of internal and external factors', of the sources of its constraints, or at what point such constraints would disqualify a great power from being a hegemon. ${ }^{18}$ Indeed, if a great power is limited in its actions by either some form of material, institutional, or other constraint, in what sense can it be said to be dominant?

In most applications, however, all three terms normally are defined in terms of 'crude' measures of material power (military and economic as Jervis does in the case of primacy), with only occasional and at times contradictory acknowledgement of the importance of values, shared interests and behaving 'legitimately' in the eyes of other states. Hegemons, in other words, do what they can while other weaker states necessarily suffer what they must. Brooks and Wohlforth, like Jervis, use material power as the key criterion for equating US primacy with unipolarity but conclude that: 'After all, it is influence, not power, that is ultimately most valuable' without any clear indication of what this influence might rest on beyond material capability and dominance alone. ${ }^{19}$ Jervis's treatment of 'primacy' in describing the post-war position and role of the US illustrates a similar inconsistency in usage. During a 1993 debate in International Security with Huntington, ${ }^{20}$ Jervis argued that primacy is all about dominance in 'crude measures' of material power, but then noted more recently in 2009 that unipolarity thought of only in terms of material power - the purest form of 'primacy' under his 1993 definition - is incompatible with the

18 T.V. Paul, 'Soft Balancing in the Age of Primacy'. International Security, Vol. 30, No. 1 (2005), pp. 46-71, at 53; Walt describing the US under Clinton as a 'half-hearted hegemon' expands on the external and internal constraints limiting US influence. See Stephen M. Walt, 'Two Cheers for Clinton's Foreign Policy'. Foreign Affairs, Vol. 79, No. 2 (2000), pp. 63-79.

19 Brooks and Wohlforth, 'American Primacy in Perspective', p. 32.

20 See Robert Jervis, 'International Primacy: Is the Game Worth the Candle?' International Security, Vol. 17, No. 4 (1993), pp. 52-67; Samuel Huntington, 'Why International Primacy Matters'. International Security, Vol. 17, No. 4 (1993), pp. 68-83. 
principles of international liberalism from which US power derives its legitimacy. ${ }^{21}$

Two notable exceptions to the often cavalier application of the above terms to describe the nature of US influence and leadership - its strengths, weaknesses, importance and likely longevity - are the views on great power leadership provided first by Hedley Bull in The Anarchical Society, 22 and a more recent characterization of the US role by Joseph Nye. ${ }^{23}$ According to Bull and Nye's respective treatments of dominance, hegemony and primacy, each type of leadership appears to be: (a) distinct in its meaning, determined mostly by the extent to which the authority of a given leadership rests not only on material power and the ability to coerce in the cases of dominance and hegemony, but also the legitimacy granted by those being led in the case of primacy; and (b) both a strategic end and means. Under this approach, primacy, hegemony or dominance represent qualitatively different types of leadership. Material power dominance (military and economic) may be a sufficient condition for hegemonic leadership (for instance, Beijing's apparent goal of regional hegemony), but it is only one of several necessary but insufficient conditions for primacy. Material power alone, in other words, can be a sufficient condition for hegemony, but only in the short term.

The power to persuade and influence without coercion - the hallmark of primacy - is what sets primacy apart from hegemony and dominance, according to Bull. ${ }^{24}$ Nye similarly distinguishes between primacy and hegemony, ${ }^{25}$ echoing Huntington's view of primacy being about the ability to exercise influence over the behaviour of more actors on more issues than any other government can. ${ }^{26}$ Like Huntington and Bull, Nye agrees on the necessity of power for primacy, but distinguishes between the types of power needed: military, economic and soft, or what Huntington essentially treats as political power and the opportunities it provides to persuade and resolve differences without necessarily going to war. Indeed, for all three perspectives, a commitment to shared political and economic values and interests, in addition to military and economic

\footnotetext{
21 Jervis, 'Unipolarity', p. 202.

22 Hedley Bull, The Anarchical Society (New York: Columbia University Press, 1977).

23 Joseph Nye, ‘American Hegemony or American Primacy?' Project Syndicate (9 March 2015). Available at: https://www.project-syndicate.org/commentary/ american-hegemony-military-superiority-by-joseph-s-nye-2015-03?barrier=accessreg.

24 Bull, The Anarchical Society, pp. 208-9.

25 Nye, 'American Hegemony or American Primacy?'.

26 Huntington, 'Why International Primacy Matters', p. 68.
} 
superiority, are entirely necessary for primacy, and therefore also a type of leadership that is more enduring than one based only on material power.

Jervis's point about the liberal order creating conflict with unipolarity, which he equates with hegemony, further illustrates the problem presented by Ikenberry's description of 'liberal hegemony'. Posen goes further here by characterizing liberal hegemony and its maintenance which he describes as 'the consensus grand strategy' in Washington - as inherently expansionist rather than status quo. ${ }^{27}$ But if an order is about expansion, rather than maintaining a stable status quo, the idea of 'order', especially one based on juridical equality, and the stability normally associated with order becomes very problematic, if not contradictory. Posen argues against the pursuit of liberal hegemony as a grand strategy, proposing instead a more realpolitik and realist-based strategy of 'restraint' for the US, one which recognizes both the limits of US power and influence, and the risks of liberal activism. ${ }^{28}$ Interestingly, and although Posen presents primacy as material superiority applied for liberal hegemonic ends, Posen's argument for restraint implies a style of leadership closely resembling the characterizations of primacy - and the type of leadership it engenders - offered by Bull, Huntington and Nye.

As indicated above, the many differences in how hegemony and primacy are understood are long-standing, as are the different perspectives on the nature of US leadership, its sources of authority, and the degree to which it is an 'indispensable' condition for stability and prosperity. We cannot conclusively resolve the debates and differences here, but we do stress the importance of being clear about the character of US leadership and its sources of authority when attempting to understand why it is (or is not) compelling for others. Each of the authors in this volume have their own views on the nature and defining attributes of US leadership, its prospects, and why it is important to US allies and partners in the region; none more so than Australia and Japan.

We therefore leave open for now the question of which term or terms might best describe US leadership and why it remains sought after, albeit for different reasons, by so many states. We will return to this question, along with the others we have posed above, in the concluding chapter where we tie together the characteristics assigned to US leadership and its long-standing importance for Australia and Japan in each chapter. Doing so provides different perspectives on the US leadership role from

27 Posen, Restraint, pp. 67-8.

28 Posen, Restraint, pp. 164-75. 
Japan, Australia and the US along with some grounds for offering a judgement on whether US power and influence are more usefully understood as the product of hegemony or primacy, at least in the context of understanding Australia-Japan bilateral security relations and how these relations are likely to evolve in the future.

\section{OVERVIEW OF CHAPTERS}

The chapters in this book provide key insights into the nature of US leadership in the Asia-Pacific through the prism of Australia and Japanese perceptions and from the perspective of how these perceptions shape the bilateral relationship between Tokyo and Canberra. The contributors to the book are also concerned with outlining what can be done to further promote regional stability and ongoing American engagement in a context where uncertainty is intensifying over the endurance of US alliances and global commitments more generally. Each chapter outlines the characteristics it assigns to US leadership in terms of the author's perspective on whether this leadership has been an effective driver of security cooperation and engagement between Australia, Japan, and other states in the Asia-Pacific. Guided by their particular focuses, the chapters examine and draw conclusions on the questions outlined at the beginning of this chapter.

There are four prominent themes that emerge from across all the chapters. The first is that, while the post-war 'hub and spokes' alliance system has become outdated in the sense that its initial purpose is no longer pertinent, it is still important for the evolution of a new system of security relations in Asia. Second, Australia and Japan remain strongly committed to their alliances with the US and to supporting continuing US leadership of the current order. Their bilateral relationship, and the Trilateral Security Dialogue with the United States instituted in 2006, provide an important foundation for further expanding security relations in the region. Third, notwithstanding the advent of the Trump administration, which has indicated ambivalence about the cost-benefit value of alliances, uncertainty over the durability of the US commitment to its security guarantees is not new and will continue to be a factor shaping security thinking in Canberra, Tokyo and elsewhere. The extent to which the US would be prepared to accommodate China's growing strategic interests became a concern for allies, especially Japan, under the Obama administration, and this has continued under the Trump administration, which has conveyed mixed signals about its long-term commitment to maintaining US leadership in the Asia-Pacific. 
Fourth, managing the fluid regional security environment in the context of growing uncertainty over US foreign policy and Washington's commitment to East Asia is the immediate challenge confronting Australia, Japan and other US allies in the region. Increased security cooperation between US allies and with other security partners in the region (for example, Vietnam, Singapore, Indonesia) is an approach that pays dividends both in addressing the Trump administration's demands for a greater material contribution from US allies, but also in hedging against a possible drawdown of US engagement in the region as President Trump doubles down on his pursuit of an 'America First' foreign policy.

For organizational and thematic purposes, the book is divided into five parts. Part I examines US leadership of East Asia's liberal, rules-based order. Here, Ian Hall and Michael Heazle examine the regional order's liberal character and sources of legitimate authority, its evolving nature under US leadership, and the requirements imposed on leadership by a distinctly liberal order. They argue that there are two distinctive challenges facing what they term the region's 'status quo' states: upholding legitimate authority to underpin the liberal rules-based order in East Asia; and ensuring an appropriate balance between the normative underpinnings of rules and core state interests. According to Hall and Heazle, the regional political order's liberal character is under challenge from China, but doubts are emerging over Washington's willingness to confront this challenge. While the post-war rules-based order has served East Asia well, the signs are not promising that the Trump administration will invest sufficient political and strategic capital in defending this order.

Van Jackson's chapter begins Part II by analysing the claim that the US is pursuing primacy in the Asia-Pacific. Jackson takes issue with this claim and argues that evidence of strategic friction between the US and China does not confirm ambitions of primacy on the part of Washington. For Jackson, this is equally true of the Obama and Trump administrations and he further argues that were the Trump administration to embrace a strategy of primacy, it would be a major departure for US policy in the region. In her chapter, Mira Rapp-Hooper discusses how America's allies in Asia can build upon former US Defense Secretary Ashton Carter's notion of 'networked security', which promotes deeper multilateral ties among like-minded states. This, according to Rapp-Hooper, can help to hedge against China's rise while taking into account growing fiscal limitations on America's capacity to lead on every security issue in the region. Such an approach is particularly important from Rapp-Hooper's perspective in light of the Trump administration's ambivalence regarding the value of alliances. 
In the final chapter of Part II, Zack Cooper questions the sustainability of the traditional hub and spokes alliance model in Asia given increasing questions over the ability of the United States to provide leadership in the region. Cooper's analysis stresses that although the hub and spokes system has exhibited striking stability since the 1950s, rising doubts over US leadership are putting a premium on the ability of regional allies to themselves become hubs in the system. In practice, this will mean allies needing to bear more of the alliance burden in partnership with the US while at the same time actively encouraging successive US administrations to remain strongly engaged in the Asia-Pacific.

Part III moves the book's focus more squarely towards Japanese and Australian perspectives on US regional leadership. Satoru Mori provides a Japanese perspective on the Obama administration's rebalance, the Trump administration's early approach to the Asia-Pacific, and the implications of this for Japan's expectations of US leadership. Mori argues that US leadership depends not only on the reaffirmation of existing treaty commitments and the level of actual military presence, but also on the extent to which the United States is willing to take on the risks and costs of enforcing shared rules and norms in the region and beyond. He further argues that, despite the 2011 rebalance, the Obama administration effectively stepped back from upholding US leadership in the region by failing to adequately deter China from asserting its authority on major territorial disputes. According to Mori, this was part of a broader US strategy of devolving responsibility to allies in the region to safeguard their security, as well as a desire to build deeper cooperation with Beijing in responding to global challenges such as climate change.

In his chapter, Ryo Sahashi traces the historical development of Japanese strategic policy from the Cold War through to contemporary concerns over China. Sahashi highlights the centrality of US regional leadership in Japanese security thinking, but argues that this thinking is experiencing a transformation. In particular, Japanese strategists are looking to address growing doubts about American leadership by reaching out to like-minded regional states with a view to maintaining a favourable regional security order. Sahashi argues that the advent of the Trump administration has accelerated this process of review as Japanese elites take note of the shift in US rhetoric concerning alliances and the rising costs of regional leadership. Sheryn Lee investigates in her chapter the at times robust debate in Australia over the US role in the AsiaPacific and the future of the bilateral security alliance. Lee's analysis focuses on the views of what she labels 'declinists', 'sceptics' and 'moderates' and how these views on the alliance relate to the so-called 'China choice' debate. Lee makes the case that the position of moderates 
in the debate - which underscores the nuances inherent in Australia's regional relationships - is a compelling but often overlooked perspective, one that is gaining enhanced currency under the Trump administration.

Part IV looks at the prospects and challenges for deeper AustraliaJapan security engagement to encourage continuing US leadership and support for the liberal order. Rikki Kersten's chapter discusses how closer security relations between Canberra and Tokyo have helped to strengthen the overall alliance system in Asia while analysing the prospects for a formal security alliance between Japan and Australia. Although she is sceptical about the latter, Kersten sees great potential for the further strengthening of the Australia-Japan security relationship, notwithstanding Tokyo's disappointment at the Sōryū submarine tender bid being unsuccessful in 2016. Indeed, Kersten's assessment is that closer Australia-Japan security relations have become less contingent on US leadership over time, and that Canberra and Tokyo increasingly see their bilateral ties as a hedge against declining US leadership in the Asia-Pacific, including with respect to upholding liberal norms such as free trade. Finally, Ryosuke Hanada examines the evolving nature of Japanese security policy in the Asia-Pacific. Hanada details the various initiatives taken by Shinzo Abe to strengthen Japan's capacity to play a more proactive role in regional security, particularly regarding China and its increasingly assertive behaviour. Despite acknowledging the range of views shared by Tokyo and Canberra on key dimensions of the regional security environment, like Kersten, Hanada remains sceptical that a formal alliance is in the offing.

The book's final section, Part V, provides the book's conclusion, where we compare and contrast the core arguments of each chapter and seek to integrate the key themes of the analysis. The main focus of the conclusion is an outline of how the chapters have overall addressed the three central questions of the volume posed at the outset of the current chapter. 